the bit about geometrical illusions such as the Müller-Lyer and Poggendorf effects. For example, the authors ignore Glass's suggestion that the latter effect is enhanced by optical blur, along with virtually all other relevant psychophysical work. In general, the book is much stronger on polemic than on hypothesis testing.

After reading the book, I wasn't sure that I had understood the theory, so perhaps I have not done it justice. The summary at the end talks of retinal stimuli triggering 'reflex responses' that have been learned over time. There have been several behavioural theories of perception: is this another? Concerning reflexes, it is interesting to think of the celebrated McCullough effect, in which prolonged inspection of tilted, coloured lines causes achromatic lines of the same (but no other) tilt to have the complimentary hue to the 'conditioning' colour. According to the 'empirical theory', shouldn't they have the same colour? Shouldn't the 'waterfall after-effect' go in the same direction as the bayesian-biasing waterfall? Perhaps the theory can be refuted after all.

Michael Morgan is at the Applied Vision Research Centre, City University, Northampton Square, London EC1V OHB, UK.

\section{Discovering geological time}

The Man Who Found Time: James Hutton and the Discovery of the Earth's Antiquity

by Jack Repcheck

Perseus: 2003. 229 pp. US\$26, Can $\$ 40$

Simon \& Schuster: 2003. 115.99

\section{David R. Oldroyd}

The Man Who Found Time is an example of a genre of science history that frequently appears in airport bookshops. The author takes an important figure or theme in the history of science - often one little known to the general public - and writes about it in a pleasant and engaging way, telling a story that deserves to be widely known. Such books seemingly make good money for publishers and authors, and are likely to be reviewed widely in journals such as Nature. So it is surprising how few professional historians of science have grasped such attractive opportunities.

These 'airport lounge' books seem to be creatures of publishers as much as authors. But why do publishers choose amateur science historians as writers? Who has the idea for these books: the authors or the publishers? Who does the real work in getting these books out? These thoughts are prompted by Jack Repcheck's enormous list of acknowledgements, among whom the agent, the

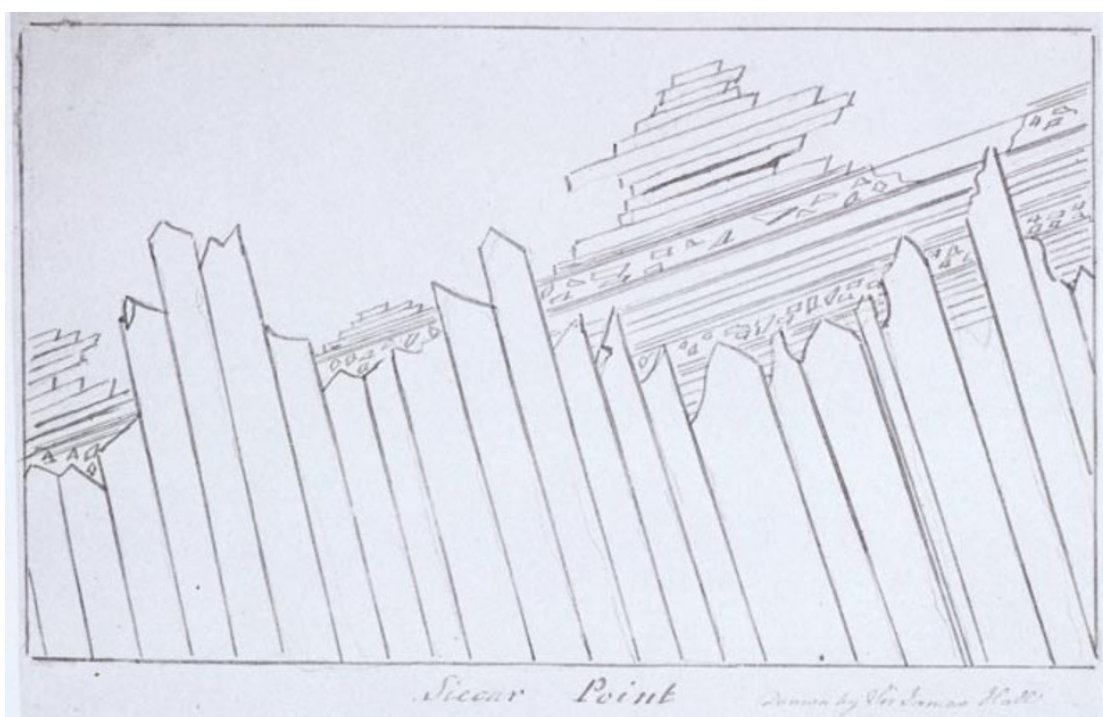

Rock solid: drawings of Siccar Point support James Hutton's ideas about the vastness of geological time.

publisher's staff and the editor are given special thanks. Repcheck also thanks various Hutton scholars for doing "research and spadework" without which the book "would have been impossible".

With all that back-up, one might expect a superior product. However, I was initially provided with a pre-publication version of the book. This gave me an insight into the author's uncertain grasp of the facts. The early copy was littered with so many errors that I asked to be supplied with the final version of the book before attempting a review. When it arrived, I was pleased to see that many of the obvious glitches had been dealt with (for example, Derby was now a town and not a river). But the principle of universal gravitation was still described as "the first natural law to be identified" (what about the laws of reflection and refraction?). Some erroneous definitions of geological terms had been corrected, but incongruities remained, such as the idea of "vacillation" between marine and terrestrial environments.

Having said this, the theme is worthwhile and the text is pleasantly written. After an (unnecessarily lengthy) account of how the idea of a young Earth was established, based on biblical and other historical records, Repcheck sketches some of the main events of Scottish eighteenth-century political history, Hutton's Edinburgh environment, his intellectual milieu, and his personality, career, ideas and achievements. He then gives an incomplete account of Hutton's scientific work, and carries the story through to the work of Charles Lyell and Darwin.

Naturally, I accept that Hutton was a pivotal figure in the history of geoscience and deserves to be much more widely known. He considered weathering and erosion, and developed a cyclic theory of Earth's history. Sediments were thought to be consolidated by the Earth's hypothesized internal heat.
From time to time, magma was supposedly intruded into the Earth's crust, elevating land and forming new rock that in time would weather and erode to form new soils and eventually sediments. So while constantly changing, the Earth is a grand system in which the formation and destruction of rocks is balanced and conditions suitable for human existence maintained.

Hutton predicted the occurrence of unconformities, and confirmed his predictions in the field. When he examined a remarkable unconformity on the Berwickshire coast (at Siccar Point) with friends, they felt they were looking into the "abyss of time". The immensity of time that Hutton's grand cycles of geological change required could be seen from the arrangement of the rocks. Without such work, Lyell and Darwin would not have been able to do what they did.

Repcheck outlines this argument satisfactorily, but there are serious gaps in his account. No mention is made of Hutton's work on philosophy or his unpublished treatise on agriculture (which adumbrated the idea of natural selection). Repcheck insists on the significance of Hutton's chemical ideas, but says nothing about his ideas on phlogiston and 'solar substance', which were important in his overall theory (to the extent that some Gaia aficionados regard him as one of their forebears). Little is said about Hutton's methodology, and there is nothing about his claimed intellectual debt to the earlier work of Robert Hooke (described in Ellen Drake's 1996 book Restless Genius), other than saying that Hooke's work offered one of the important precursory publications for Hutton.

More seriously, there is no mention of how Lyell's observations of the still-standing columns of an ancient building at Pozzuoli in the Bay of Naples influenced Lyell's ideas about elevation and subsidence. Even more 
importantly, given the book's theme, nothing is said of Lyell's interpretation of the accumulation of Mount Etna's lava flows, which overlie geologically quite recent rocks, as evidence for the Earth's great age. But I should be surprised if the author knew about such matters, his knowledge of the history of geology literature evidently being limited.

All in all, the book reveals the author as an amateur historian of science, leaning on the work of others and not doing justice to his important theme. Yet the book will doubtless sell well with the publishers' backing. In contrast, another semi-popular, but authoritative, book by the Hutton scholar Donald McIntyre (with Alan McKirdy), James Hutton: The Founder of Modern Geology (The Stationery Office, 1997), received insufficient funding to accommodate references and had only a very brief bibliography and a modest print run. Why should this be so? David R. Oldroyd is at the School of History and Philosophy of Science, University of New South Wales, Sydney, New South Wales 2052, Australia.

\section{Eyes on the prize}

How to Win the Nobel Prize: An Unexpected Life in Science

by J. Michael Bishop

Harvard University Press: 2003. 320 pp. $\$ 27.95, £ 18.50, € 27.95$

\section{István Hargittai}

If offered reincarnation, the Nobel laureate J. Michael Bishop would choose to come back as a musician (with exceptional talent, to be sure), because he thinks that one lifetime as a scientist is enough. The son of a lutheran minister, he grew up in rural Pennsylvania, and became enchanted with research during his last years at Harvard Medical School. He has been at the University of California, San Francisco since 1968, and worked for 15 years with his former postdoctoral associate, and ultimately fellow Nobel laureate, Harold Varmus.

Their work had its roots in the discovery of a cancer-causing virus in chickens by Peyton Rous in 1911, who was awarded the Nobel Prize fully 55 years later. Five individuals then went on to win Nobel Prizes for related work. David Baltimore, Renato Dulbecco and Howard Temin won in 1975 "for their discoveries concerning the interaction between tumour viruses and the genetic material of the cell", and Varmus and Bishop became Nobel laureates in 1989 "for their discovery of the cellular origin of retroviral oncogenes". Baltimore and Temin found the viral enzyme reverse transcriptase, which allows RNA to be copied into DNA, a reversal of the normal flow of genetic information. This discovery could have been Bishop's had he been more daring. However,

\section{Illustration}

\section{A fine body of work}

Leonardo da Vinci's anatomical drawings, such as those of the shoulder shown here, may have been undertaken primarily out of an artistic desire to perfect his representation of the human body. They were influenced by the prevailing dogma of medical anatomy, as established by the Greek anatomist Galen some 1,400 years earlier. Leonardo's focus on drawing from life - in particular from his first-hand observation of human dissection - clearly informed his later works. The accuracy of his representations of human anatomy often surpassed that of contemporary medical experts. A massive book containing all of Leonardo's sketches, together with an analysis of the artist's work - Leonardo da Vinci 1452-1519: The Complete Paintings and Drawings (Taschen) by Frank Zöllner - has recently been published. Mary Purton

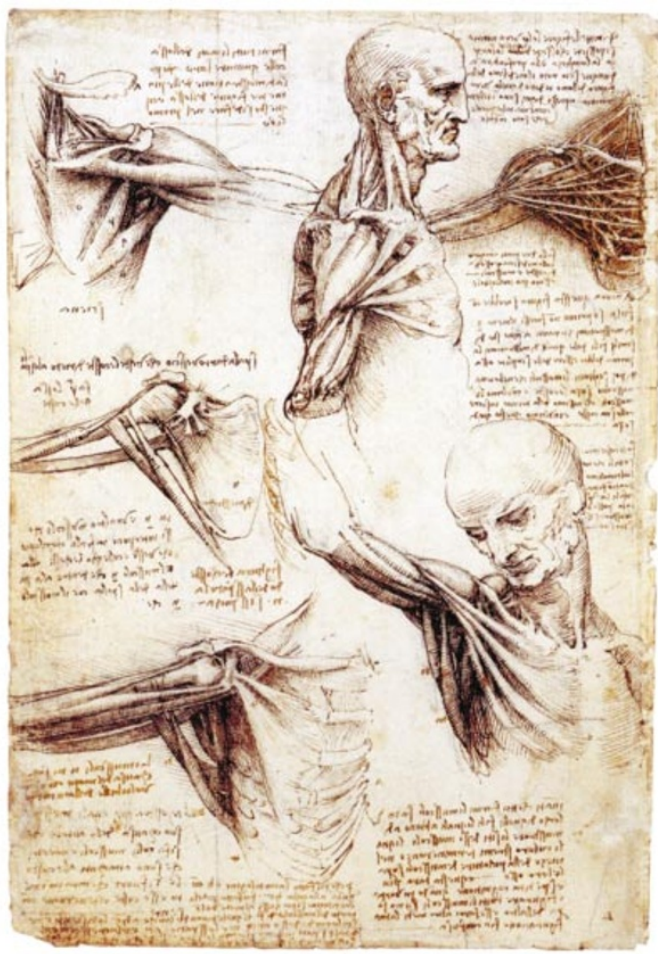

he learned his lesson and was fortunate enough to get another chance.

The discovery of oncogenes (cancer genes) raised the question of whether such genes might be present in the genetic composition of normal as well as cancerous cells. Locating them carried the promise of understanding human cancer at the genetic level. At first it was thought that oncogenes were viral genes, but Bishop and Varmus discovered that they were cellular genes that had been kidnapped by the virus. It took their team four years to identify them.

Bishop quotes a beautiful description of a moment of discovery by one of their postdocs, Dominique Stehelin: "The intensity of the emotion I experienced and the intellectual clarity induced by the situation at that moment were very special." Furthermore, "I suspect that few have the privilege of enjoying such a moment when one is intensely and profoundly aware that a major step forward in Science has been made, and that one has contributed to it." Alas, the quote was from an open letter to the Nobel Committee by Stehelin, who was not among the Nobel awardees. For every Nobel laureate there are others who might have also been included but were not, and every story about how to win the Nobel Prize may have its counterparts.

Bishop does not give a recipe for winning the prize, as any attempt to emulate a particular research career would be doomed to fail. However, throughout the book, he makes important points that budding scientists may find useful. For example, it is more useful to learn from one's peers than from one's teachers. Start a research career in a place where you feel genuinely needed, rather that choosing somewhere for its prestige. Being a pioneer in research is fun, although it may bring more fame to be part of a team completing a discovery. Give a name to your discovery as soon as it is made. And finally, Bishop points out, good scientists should also market their ideas well.

Nobel laureates often seem to be standardbearers for good causes, usually by signing petitions or making statements about issues with which they may not even be too familiar. Bishop'sinvolvement in public causes has been different. He actively organized the participation of scientists in a non-partisan movement to increase legislative attention for science. Their high-level lobbying helped to achieve record support for research from taxpayer's money in the United States.

Bishop compiled his experience and ideas in this book for the general public. He also provides a crash course on the microbial world that is a gem of instruction without being condescending. And his copious use of art, including poetry, is a statement about the unity of the two cultures.

István Hargittai is at the Budapest University of Technology and Economics, Szt. Gellert ter 4, H-1521 Budapest, Hungary. He is the author of The Road to Stockholm: Nobel Prizes, Science, and Scientists. 